\title{
A novel approach to oligonucleotide synthesis using an imidazolium ion tag as a soluble support
}

\author{
Robert A. Donga; Syed M. Khaliq-Uz-Zaman; Tak-Hang Chan*; Masad J. Damha*
}

\section{Table of Contents}

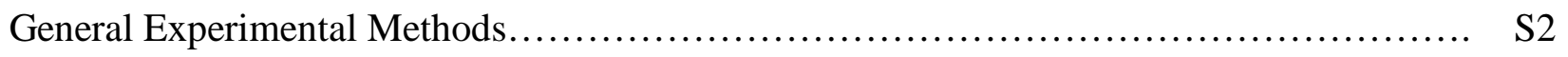

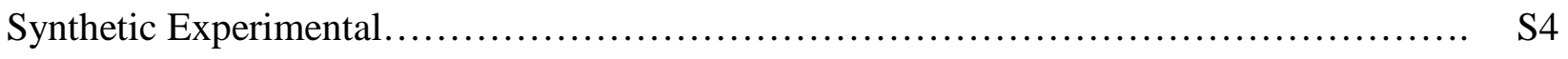

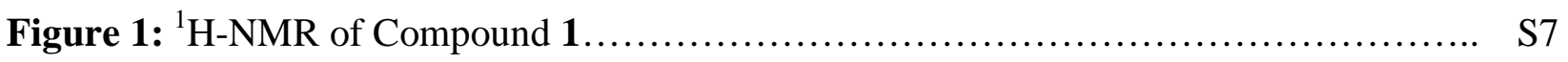

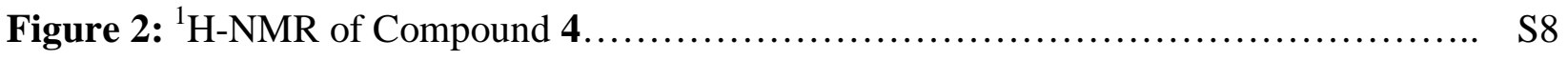

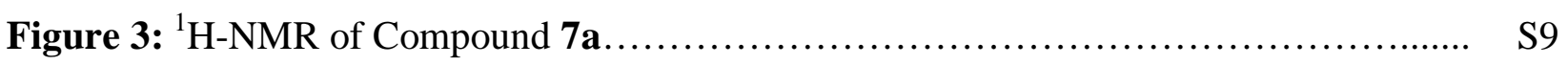

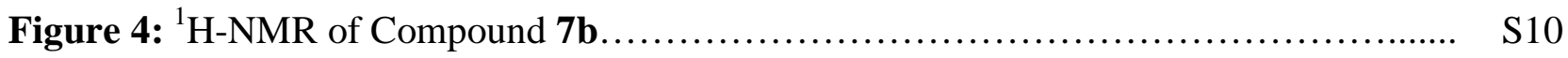

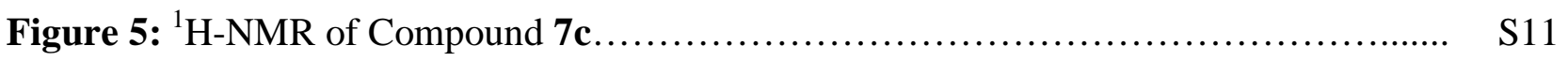

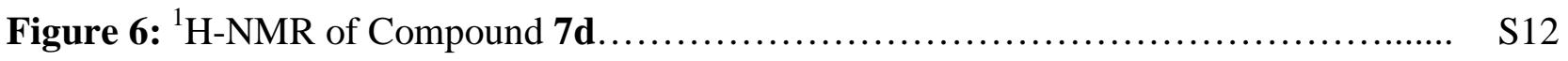

Figure 7: HPLC Chromatographs of Deprotected Oligonucleotides 12a-f............... S13

Scheme 2: Oligonucleotide Coupling Cycle.............................................................. S14 


\section{General Experimental Methods}

All reactions were carried out in oven-dried glassware under an $\mathrm{N}_{2}$ atmosphere. Acetonitrile $\left(\mathrm{CH}_{3} \mathrm{CN}\right)$ and pyridine (Py) were dried by refluxing and distilling over calcium hydride $\left(\mathrm{CaH}_{2}\right)$ under an $\mathrm{N}_{2}$ atmosphere. Tetrahydrofuran (THF) was dried by refluxing over sodium and benzophenone under an $\mathrm{N}_{2}$ atmosphere and collected before use. Anhydrous ethanol (EtOH), 4,5-Dicyanoimidazole (DCI), Chloroform $\left(\mathrm{CHCl}_{3}\right)$, dichloromethane $\left(\mathrm{CH}_{2} \mathrm{Cl}_{2}\right)$, ethyl acetate (EtOAc), diethyl ether, methanol, iodine, sodium bisulphite, sodium sulphate, ammonium hydroxide, triethylamine, acetic acid, 1-methylimidazole, 2-bromoethanol, succinic anhydride, sodium tetrafluoroborate, 4-dimethylaminopyridine (DMAP), dicyclohexylcarbodiimide (DCC), trifluoroacetic acid (TFA) 2,4,6-collidine, thymidine and all phosphoramidites were used as received from their suppliers without further purification.

\section{High resolution mass spectrometry}

High-resolution measurements were made in positive ion electrospray mode with an IonSpec 7.0 tesla FTMS calibrated with polyethylene glycol 300, 600 and 1000. 


\section{Solid-phase synthesis of oligonucleotides}

Solid phase synthesis of oligonucleotides was carried out on a $1 \mu$ mol scale on $500 \AA ̊$ long chain alkyl amine derivatized controlled pore glass (LCAA-CPG) using standard conditions.

\section{Deprotection to obtained oligonucleotides (12a-f)}

Removal of the cyanoethyl protecting group, the base protecting group (for $\mathbf{7 b - d}$ ) and the succinyl linker to the ionic liquid support was achieved by treatment of 1-5mg of compounds 7ad, as well as compounds 9 and 11, with $1.5 \mathrm{~mL}$ of $3: 1$ concentrated ammonium hydroxide to absolute ethanol at $60{ }^{\circ} \mathrm{C}$ for 16 hours or at room temperature for 48 hours. After cooling the sample, the ammonia solution was evaporated and the residue was redissolved in water and purified by ion pairing reverse phase HPLC to obtain 12a-f, respectively.

\section{Oligonucletide purification and identity confirmation}

Oligonucleotides were purified after cleavage from their respective supports by reverse phase high-performance liquid chromatography (HPLC). Separations were achieved using a 10mm x $250 \mathrm{~mm}, 10 \mu \mathrm{m}$ packing, $\mathrm{C} 1$ reverse phase column heated to $60^{\circ} \mathrm{C}$, with a mobile phase flow rate of $1 \mathrm{~mL} / \mathrm{min}$. The initial mobile phase was comprised of an isocratic flow of $100 \mathrm{mM}$ triethylammonium acetate buffer $(\mathrm{pH} 7.0,80: 20(\mathrm{v} / \mathrm{v})$ water: methanol) for 2 minutes followed by a gradient shift to $100 \mathrm{mM}$ triethylammonium acetate buffer ( $\mathrm{pH} 7.0,70: 30(\mathrm{v} / \mathrm{v})$ water: methanol) over a 35 minute period followed by 1 minute of isocratic flow before a 14 minute gradient switch back to initial condition and ending with a 5 minute period of isocratic flow. The elution was monitored on a dual absorbance detector at $260 \mathrm{~nm}$ and $217 \mathrm{~nm}$. Fractions of the eluting peaks were collected and the mobile phase was removed under vacuum. The samples were redissolved in $10 \%$ methanol-water and the molecular weights were subsequently 
determined by low-resolution electrospray ionization mass-spectrometry in the negative ion mode.

\section{Synthetic Experimental}

${ }^{\text {DMT }}{ }_{\text {Ap }} \mathbf{T}_{\text {Succ-IL }}(6 \mathbf{b})$

Compound $4(0.12 \mathrm{~g}, 0.22 \mathrm{mmol})$, adenosine phosphoramidite $\mathbf{5 b}(0.33 \mathrm{~g}, 0.38 \mathrm{mmol})$, and dicyanoimidazole $(0.33 \mathrm{~g}, 2.8 \mathrm{mmol})$ were transferred to a $50 \mathrm{~mL}$ oven dried, nitrogen purged round bottom flask. To the mixture was added dry THF or $\mathrm{CH}_{3} \mathrm{CN}$ ( $5 \mathrm{~mL}$ ) to the flask and the resulting solution was stirred at room temperature for 1-2 hours. The product was precipitated twice from $10 \%$ ethyl acetate/diethyl ether. At this point, the precipitate was redissolved in $\mathrm{CH}_{3} \mathrm{CN}$ and 2,4,6-collidine or pyridine (approximately $300 \mu \mathrm{L}$ ) was added followed by addition of an aqueous iodine solution $(0.1 \mathrm{M}$ in $\mathrm{THF} /$ water $2: 1$, excess) to oxidize the phosphite triester intermediate. After 5 min the reaction mixture was quenched with an aqueous sodium bisulphate solution $(9 \mathrm{~mL})$, diluted with $90 \mathrm{~mL} \mathrm{CHCl}_{3}$ and extracted with $50 \mathrm{~mL}$ of water. The organic phase was dried over anhydrous $\mathrm{Na}_{2} \mathrm{SO}_{4}$ and evaporated under reduced pressure to yield a foam of 6b $(0.259 \mathrm{~g}, 89 \%) .{ }^{31} \mathrm{P} \mathrm{NMR}\left(\mathrm{CH}_{3} \mathrm{CN}-d 3\right) \delta-1.324,-1.477, \mathrm{C}_{61} \mathrm{H}_{64} \mathrm{~N}_{10} \mathrm{O}_{16} \mathrm{P}^{+}$low resolution ESI-MS calculated 1223.4, found 1223.4.

${ }^{\mathrm{DMT}} \mathbf{C p} \mathbf{T}_{\text {Succ-IL }}(\mathbf{6 c})$

Compound 4 (0.11, $0.20 \mathrm{mmol})$, cytidine phosphoramidite 5c $(0.35 \mathrm{~g}, 0.41 \mathrm{mmol})$, and dicyanoimidazole $(0.37 \mathrm{~g}, 3.1 \mathrm{mmol})$ were transferred to a $50 \mathrm{~mL}$ oven dried, nitrogen purged round bottom flask. The absence of solvent prevented any reaction from occurring. The reaction was commenced by injecting dry $\mathrm{THF}$ or $\mathrm{CH}_{3} \mathrm{CN}(5 \mathrm{~mL})$ into the flask and the solution was stirred at room temperature for 1-2 hours. The same workup was employed as in case of $\mathbf{6 b}$ and 
the product was obtained in high yield as a foam of $\mathbf{6 c}(0.234 \mathrm{~g}, 91 \%) .{ }^{31} \mathrm{P}$ NMR $\left(\mathrm{CH}_{3} \mathrm{CN}-d 3\right) \delta$ 1.545, -1.754, $\mathrm{C}_{60} \mathrm{H}_{64} \mathrm{~N}_{8} \mathrm{O}_{17} \mathrm{P}^{+}$low resolution ESI-MS calculated 1199.4, found 1199.4.

${ }^{\mathrm{DMT}} \mathbf{G p T}$ Succ-IL $(6 \mathbf{d})$

Compound $4(0.13 \mathrm{~g}, 0.24 \mathrm{mmol})$, guanosine phosphoramidite $5 \mathbf{d}(0.35 \mathrm{~g}, 0.42 \mathrm{mmol})$, and dicyanoimidazole $(0.38 \mathrm{~g}, 3.2 \mathrm{mmol})$ were transferred to a $50 \mathrm{~mL}$ oven dried, nitrogen purged round bottom flask. The absence of solvent prevented any reaction from occurring. The reaction was commenced by injecting dry $\mathrm{THF}$ or $\mathrm{CH}_{3} \mathrm{CN}(5 \mathrm{~mL})$ into the flask and the solution was stirred at room temperature for 1-2 hours. The same workup was employed as in case of $\mathbf{6 b}$ and the product was obtained in high yield as a foam of $\mathbf{6 d}(0.214 \mathrm{~g}, 90 \%) .{ }^{31} \mathrm{P} \mathrm{NMR}\left(\mathrm{CH}_{3} \mathrm{CN}-d 3\right) \delta$ 1.149, -1.194, $\mathrm{C}_{58} \mathrm{H}_{66} \mathrm{~N}_{10} \mathrm{O}_{17} \mathrm{P}^{+}$low resolution ESI-MS calculated 1205.4, found 1205.6.

${ }^{\text {HO }}$ ApT $_{\text {Succ-IL }}(7 \mathbf{b})$

Compound $6 \mathbf{b}(0.26 \mathrm{~g}, 0.20 \mathrm{mmol})$ was dissolved in $\mathrm{CH}_{3} \mathrm{CN}(1-2 \mathrm{~mL})$ and $3 \%$ trifluoroacetic acid in $\mathrm{CH}_{3} \mathrm{CN}$ (2-3 mL) was added. The reaction mixture was worked up following the same procedure as for $\mathbf{4}$ giving $\mathbf{7 b}$ as a foam in high yield $(0.185 \mathrm{~g}, 93 \%)$. 31P NMR $\left(\mathrm{CH}_{3} \mathrm{CN}-d 3\right) \delta$ 1.176, -1.516, $\mathrm{C}_{40} \mathrm{H}_{46} \mathrm{~N}_{10} \mathrm{O}_{14} \mathrm{P}^{+}$high resolution ESI-MS required 921.29326, found 921.29271.

${ }^{\text {HO }} \mathrm{CpT}_{\text {Succ-IL }}(\mathbf{7 c})$

To a solution of $\mathbf{6 c}(0.23 \mathrm{~g}, 0.18 \mathrm{mmol})$ in $\mathrm{CH}_{3} \mathrm{CN}(1-2 \mathrm{~mL})$ was added $3 \%$ trifluoroacetic acid in $\mathrm{CH}_{3} \mathrm{CN}$ (2-3 mL) to generate 7c. The reaction mixture was worked up following the same procedure as for 4 giving $7 \mathrm{c}$ as a foam in high yield $(0.167 \mathrm{~g}, 95 \%) .{ }^{31} \mathrm{P} \mathrm{NMR}\left(\mathrm{CH}_{3} \mathrm{CN}-d 3\right) \delta$ 1.381, -1.613, $\mathrm{C}_{39} \mathrm{H}_{46} \mathrm{~N}_{8} \mathrm{O}_{15} \mathrm{P}^{+}$high resolution ESI-MS required 897.28203, found 897.28148.

${ }^{\text {HO }}$ GpT $_{\text {Succ-IL }}(\mathbf{7 d})$

To a solution of $\mathbf{6 d}(0.21 \mathrm{~g}, 0.17 \mathrm{mmol})$ in $\mathrm{CH}_{3} \mathrm{CN}(1-2 \mathrm{~mL})$ was added $3 \%$ trifluoroacetic acid in $\mathrm{CH}_{3} \mathrm{CN}(2-3 \mathrm{~mL})$. The reaction mixture was worked up following the same procedure as for 4 
giving 7d as a foam in high yield $\left(0.157 \mathrm{~g}, 96 \% .{ }^{31} \mathrm{P} \mathrm{NMR}\left(\mathrm{CH}_{3} \mathrm{CN}-d 3\right) \delta-1.047,-1.064\right.$, $\mathrm{C}_{37} \mathrm{H}_{48} \mathrm{~N}_{10} \mathrm{O}_{15} \mathrm{P}^{+}$high resolution ESI-MS required 903.30382, found 903.30328. 


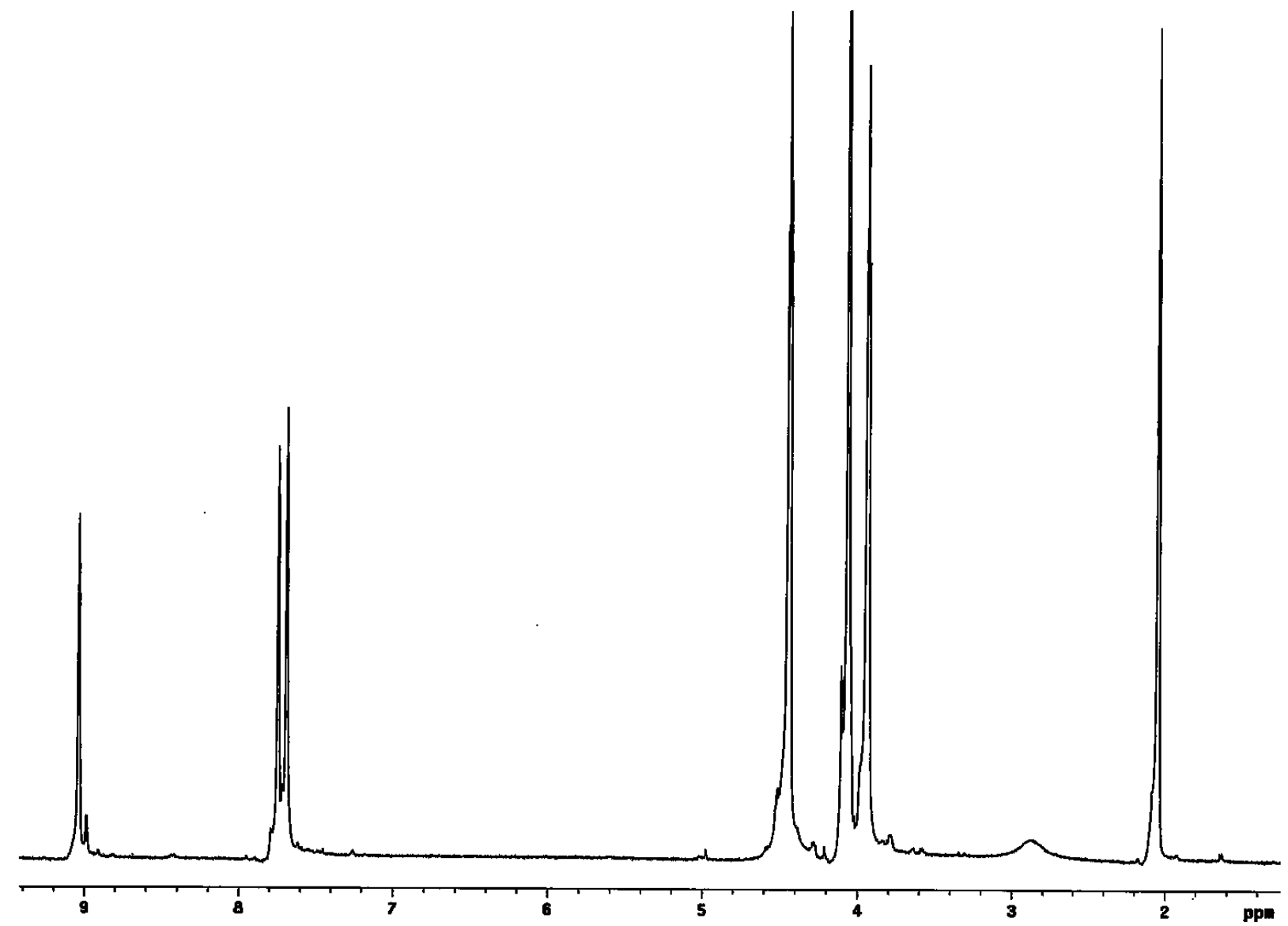

Figure 1: ${ }^{1} \mathrm{H}-\mathrm{NMR}$ of Compound 1 


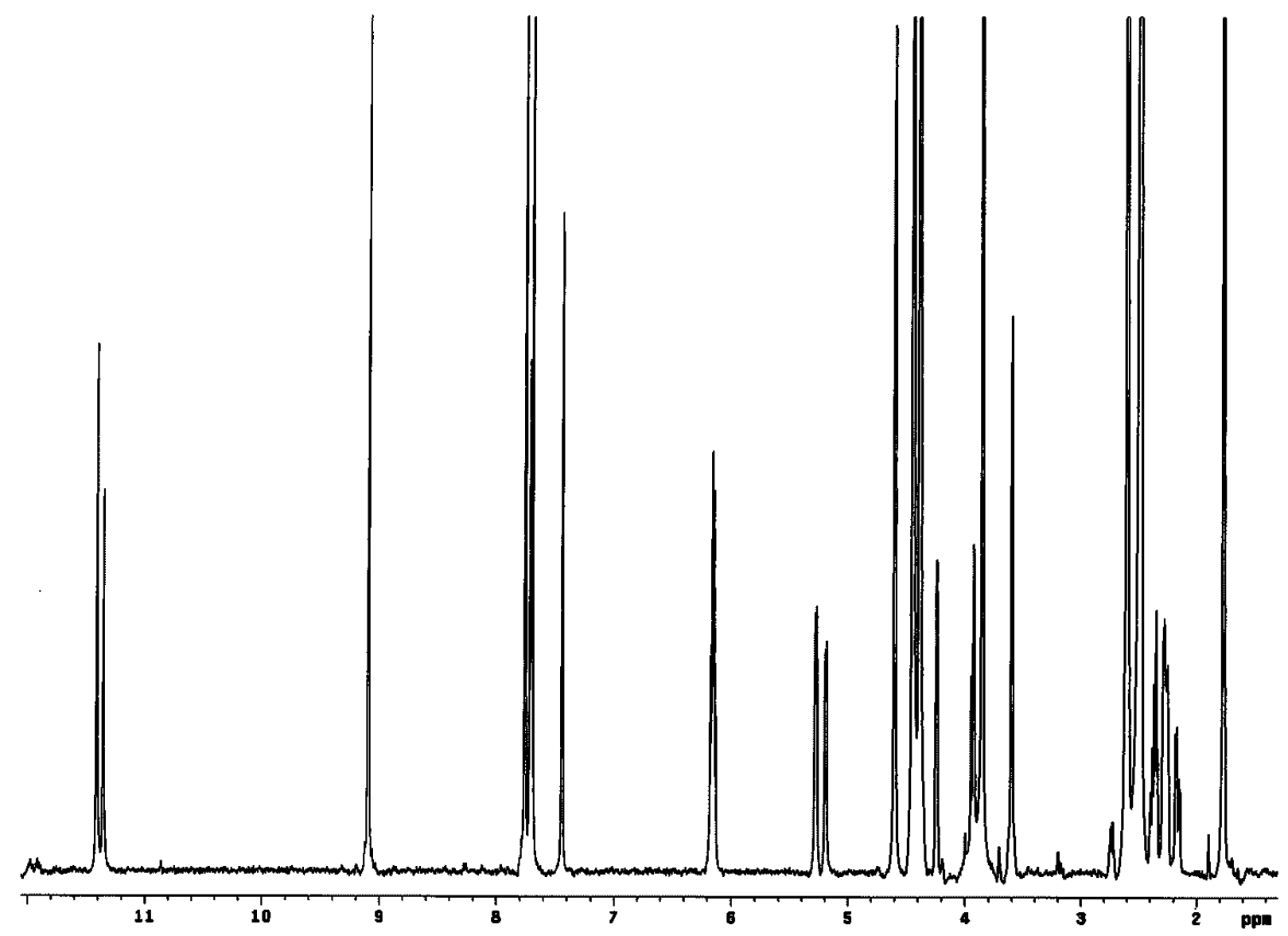

Figure 2: ${ }^{1} \mathrm{H}-\mathrm{NMR}$ of Compound 4 


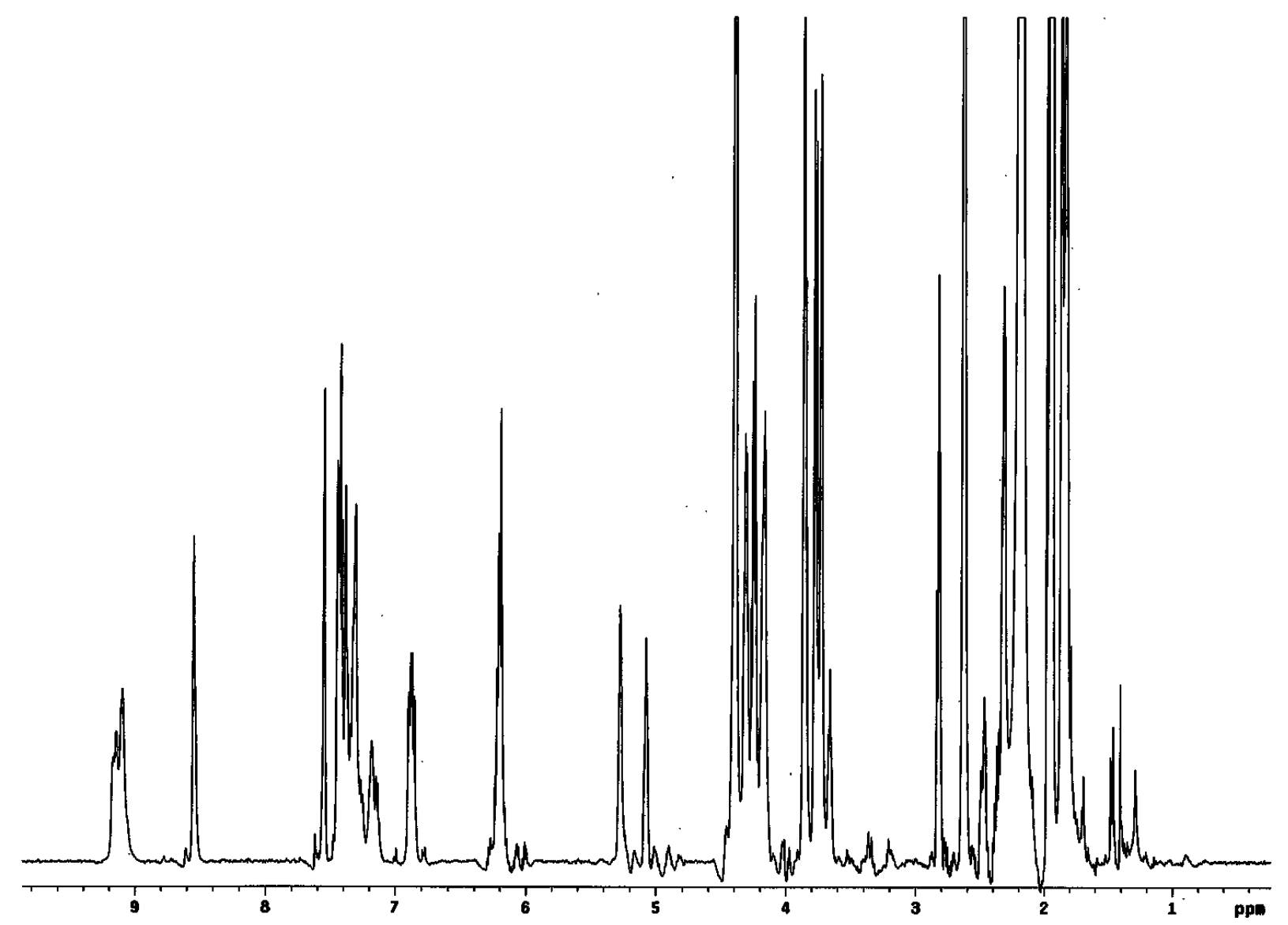

Figure 3: ${ }^{1} \mathrm{H}-\mathrm{NMR}$ of Compound 7a 


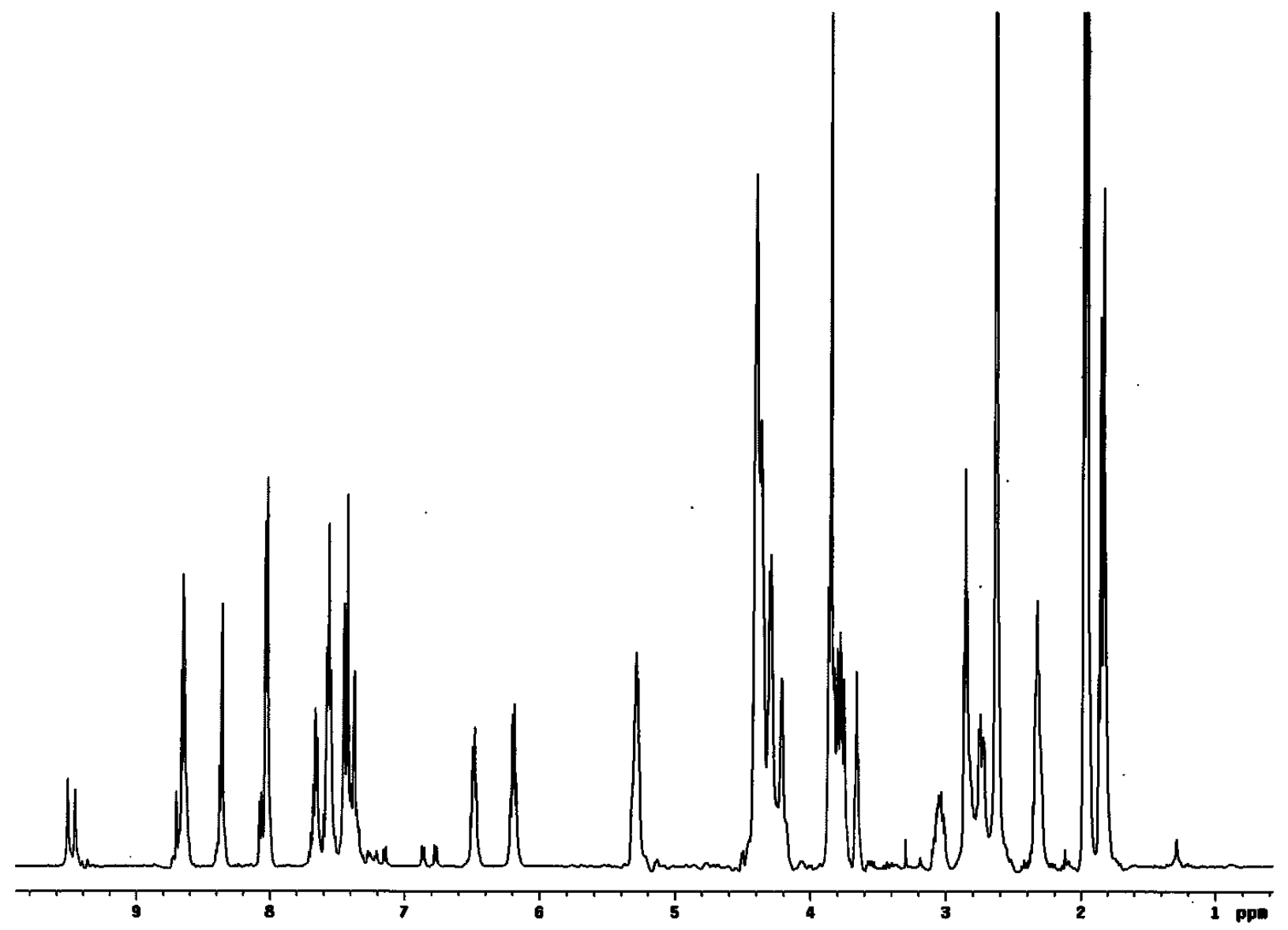

Figure 4: ${ }^{1} \mathrm{H}-\mathrm{NMR}$ of Compound $\mathbf{7 b}$ 


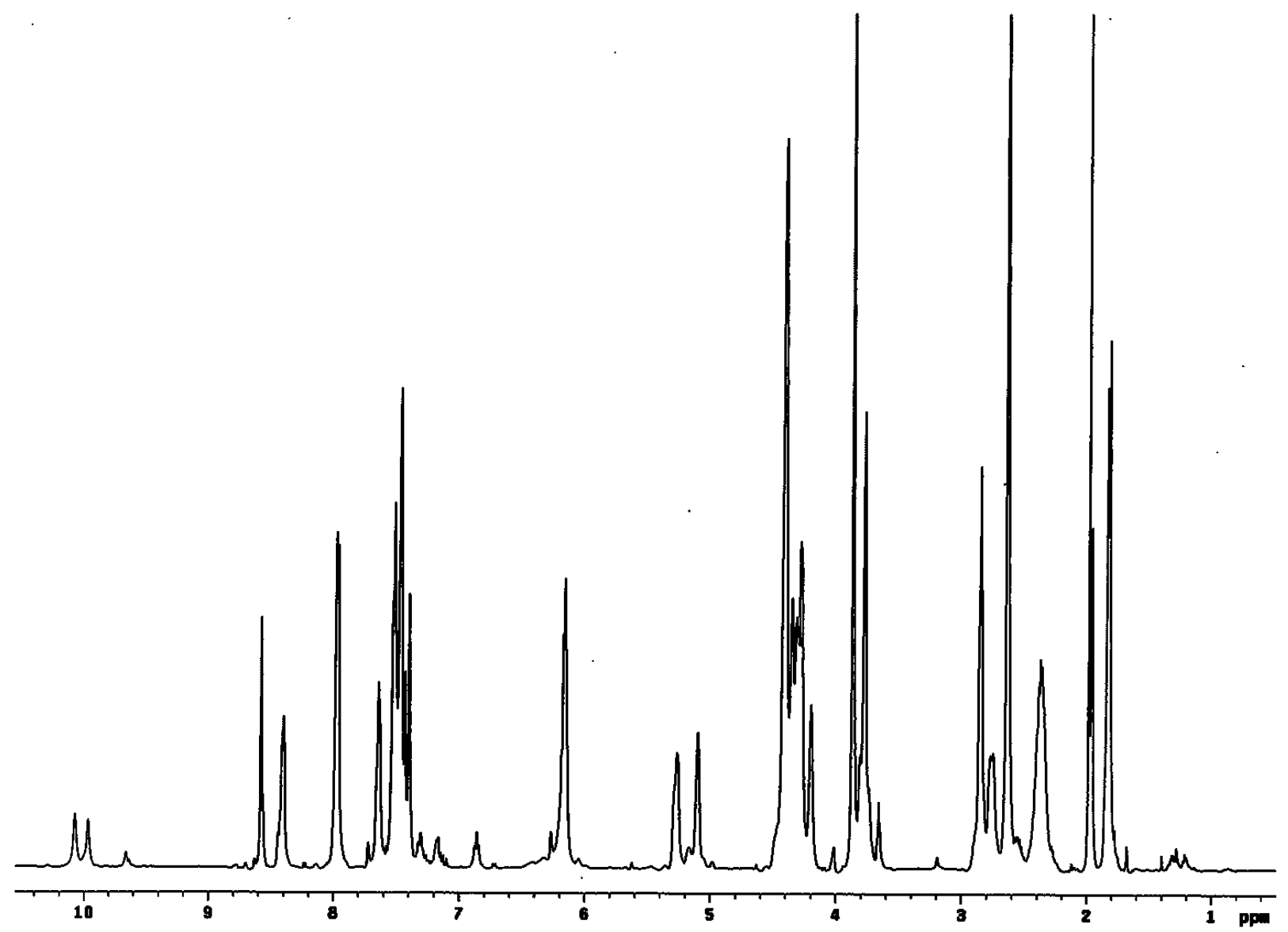

Figure 5: ${ }^{1} \mathrm{H}-\mathrm{NMR}$ of Compound 7c 


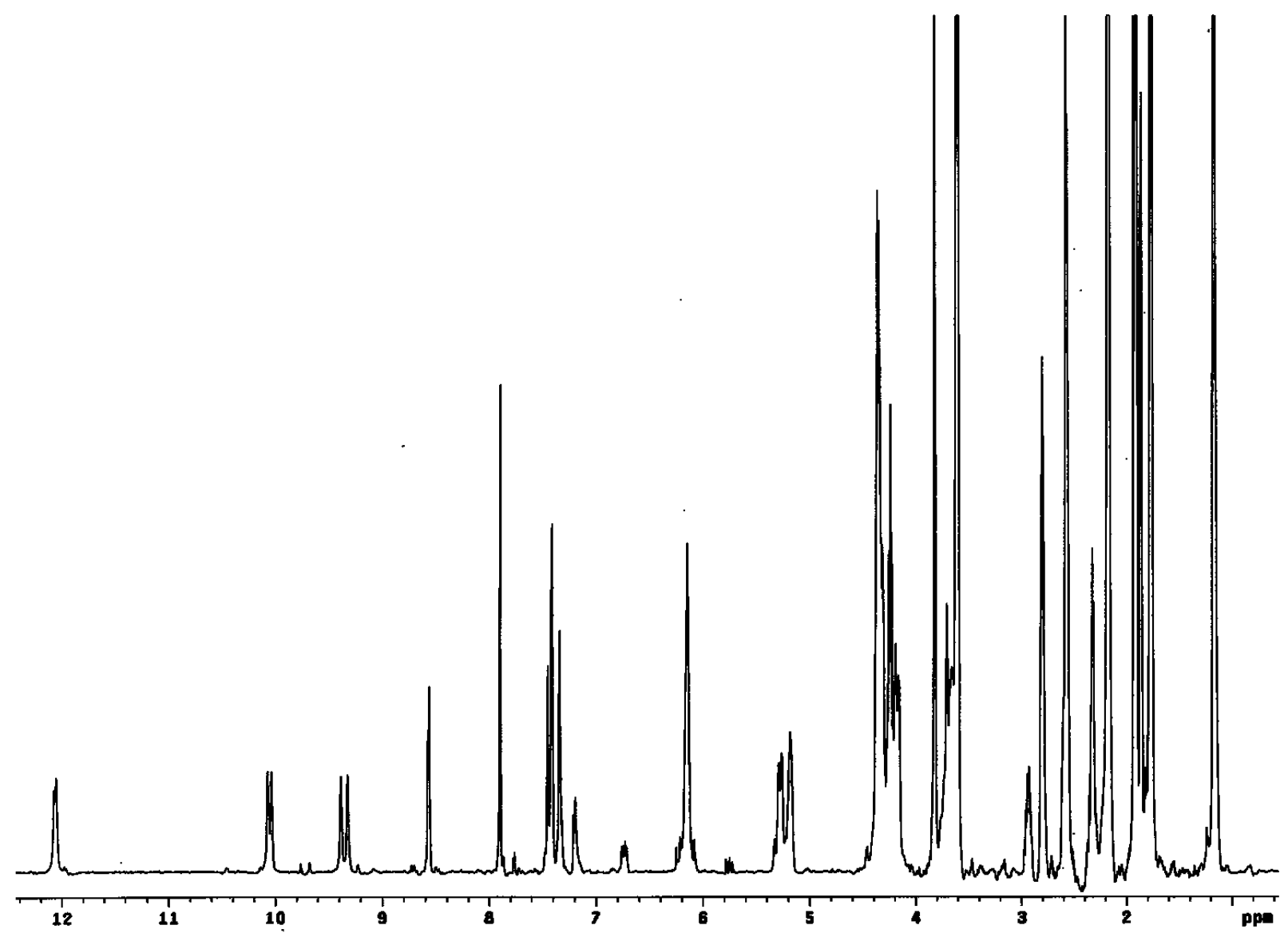

Figure 6: ${ }^{1} \mathrm{H}-\mathrm{NMR}$ of Compound 7d 

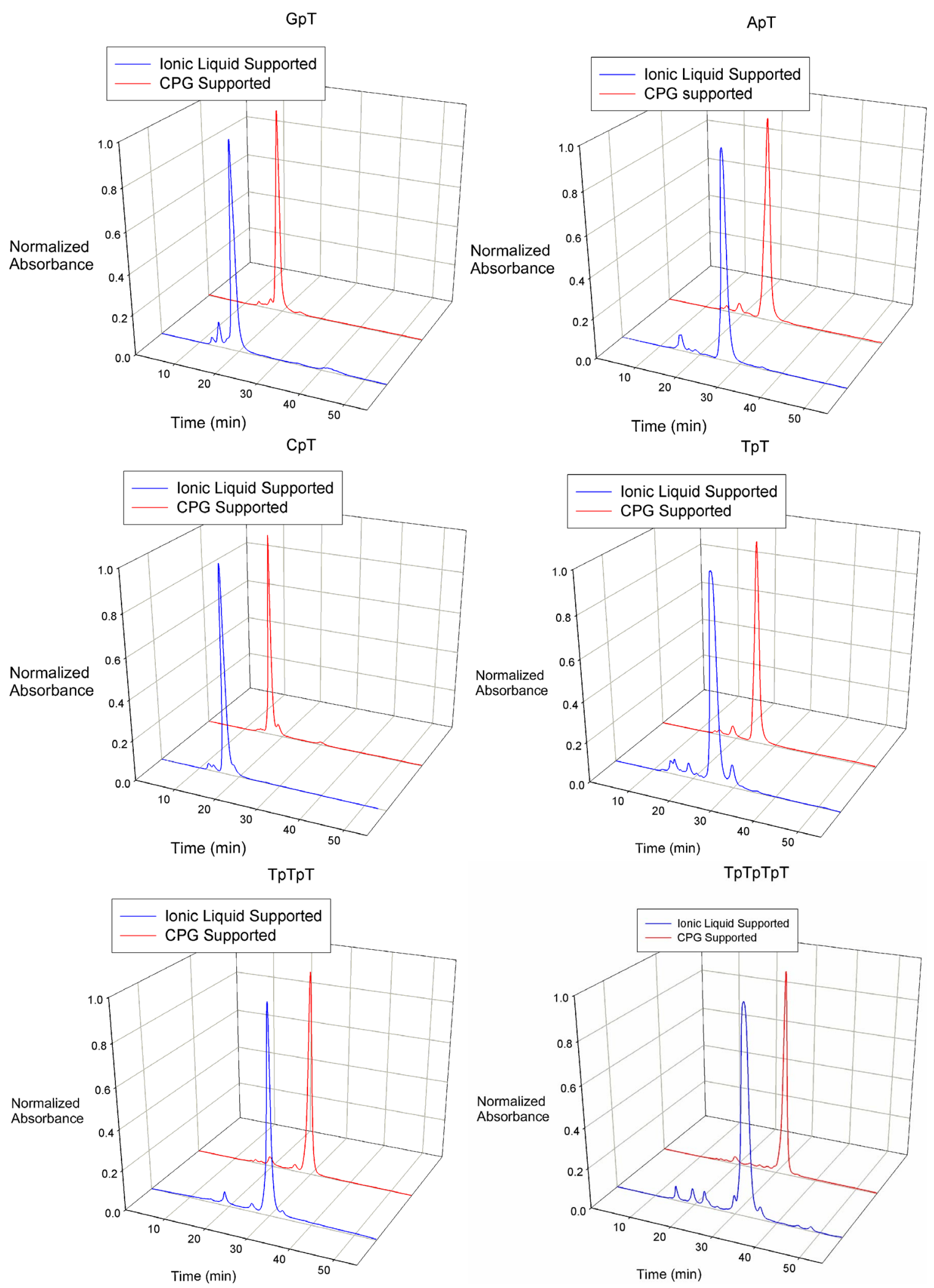

Figure 7: HPLC Chromatographs of Deprotected Oligonucleotides 12a-f 


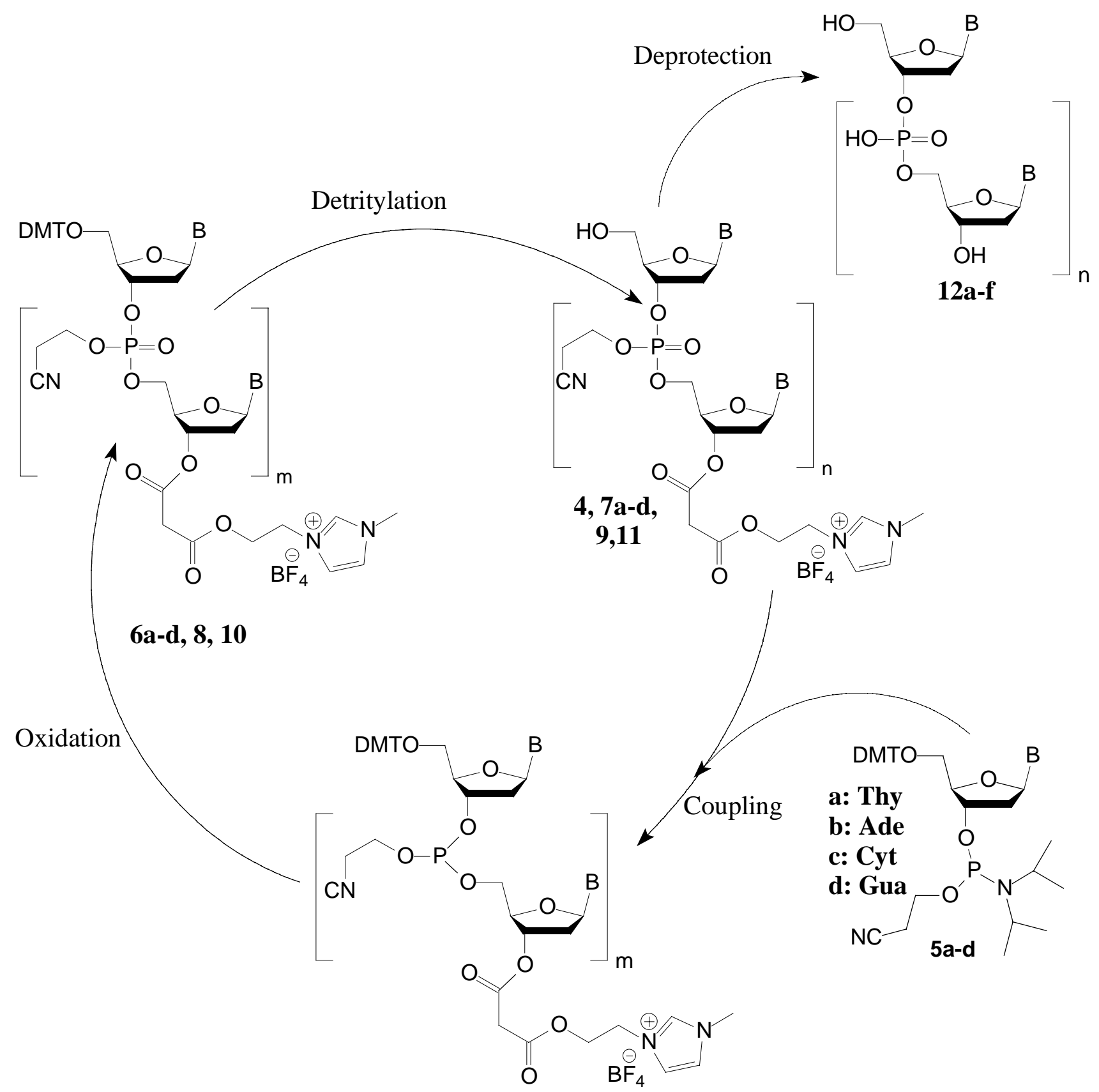

Scheme 2: Oligonucleotide Coupling Cycle 